International Economics

\title{
Iryna ZVARYCH
}

\section{CIRCULAR ECONOMY AND GLOBALIZED WASTE MANAGEMENT}

\begin{abstract}
The analysis of adaptation circular economy according to the principles of 3R (Reduce, Reuse and Recycle) is made and the fourth principle is proposed global corporate social responsibility (Responsibility), as obligatory in the formation of global circular value added chains.

Successful practical examples (startups) of the basic ideas of circular economy implementation are proposed. The circular economy should be considered at the micro, mesa and macro levels, covering production, consumption and proper waste management. Indicators of micro, mesa and macro are evaluated for implementation circular economy. Circular economy as a vector for sustainable development requires a needed shift from linear to circular way of thinking. Circular economy seeks to separate economic growth from using of the natural resources and ecosystems through more effective use of these resources.

According to the definition it is a driving force for innovation in the resource and component reuse product that is equivalent to the new business models, particularly in the service sector. Outlined prerequisites that make the circular economy like necessary business model, including the resources and pricing them, the increasing number of middle class, «big data», changing legislation and management, the transition from «agreement» to «relations». It is alleged that the transition to a circular economy means changes in thought and action,
\end{abstract}

(C) Iryna Zvarych, 2017.

Zvarych Iryna, Cand. of Economic Sciences, Assist. Prof., Ternopil National Economic University, Ukraine. 
which requires a systematic approach and affects how the business model, management, law, logistics, housing, agriculture and other will be organized and structured.

Circular economy is a system in which resource flows effectively managed and processed, executed, fully based on renewable energy sources and any action without causing adverse effects on human life and ecosystems within the formation and operation of the global circular value added chain.

\section{Key words:}

Circular economy, sustainable development of the country, the principles of $3 R$, the system of micro, mesa, macro indicators, ecosystems, natural resources, waste management, global circular value added chains, global supply chains of recycled materials, mega level, global corporate social responsibility.

JEL: Q01, Q56, Q57.

\section{Introduction}

Circular economy - is a key to solving economic tasks and environmental problems. The average person consumes $29 \mathrm{~kg}$. per day of natural resources (which corresponds to the weight of 10-year-old boy) (Brutyan, Vahromeeva, Vorozheykyna, 2016). The population continues to grow, and the rate of such consumption can't be provided. The European Investment Bank annually provides funds amounting hundreds of mln.euros to companies engaged developments in recycling and recovery of discarded products and consumer waste, but the country generating sewage waste and scrap at such rate that today they cannot useful to utilize.

But technological improvements are not a magic bullet for all problems. For example, the digitizing practice reduced paper consumption, but increased production of rare earth metals used in electronics. In addition, Erasmus University joint research shows that $8.1 \%(810000)$ of all work places in the Netherlands are now emerging with circular economy startups. This number includes all 
types of work in different fields, ranging from waste management to creative industries and creative economy.

Demonstrative fact is that the economic relevance of the concept, phenomenon or process circular economy, most practices, large corporations, analysts multinationals in terms of specific actions startups implemented policies or visionary goals. In some countries, leading firms such as General Electric, General Motors, 3M, Du Pont, Ford, Nike, Panasonic, Hitachi and others try to consider the impact of environmental and social factors in evaluating the effectiveness of an innovative project.

Expansion of ideas "greening" the economy is typical for many European countries, USA, Canada, Japan, China, South Korea, India, Australia and Brazil. Concept of ecoinnivations is relatively new and the first mention of this concept, perhaps, is found in the book of Claude F. and P. James. F. Decker, H. Krotov, G. Cramer, J. Dadzhayn, L. P. Artemenko develop problems of circular economy of different countries. The influence of resource efficiency on economic development in the countries - leaders of «green» modernization such scientists studied: K. Geiser, B.M. Danylyshyn, L. A. Musina, T. K. Kvasha, C. Morh, C. Summers .

Implementation of circular economy in China described Peng, Zhang, Huang, Wang, Jia, and Zhang. The article aims to analyze the characteristics of circular economy at the micro, mesa, macro, given some empirical research with Chinese scientists of circular economy and reflect globalized waste management in the context of circular value added chain on the mega-level.

\section{Main material}

New paradigm can be a model of circular economy based on the principles of sustainable development, the main tools of which are environmental innovation (ecoinovations) and "green» technology that is environmentally clean technologies friendly to the environment.

Circular economy - is not a traditional recycling in a new way (Brutyan, Vahromeeva, Vorozheykyna, 2016). Ideally, it begins to act well before the product comes into disrepair, need a repair or recycling. The concept of circular economy means direct participation in the stages of planning and development of products to ensure a long life cycle and high potential for future re-use, upgrading, renewal and recycling. Fortunately practical examples of implementation of the circular economy basic ideas are following startups (Potapenko, 2012, p. 23): 
- Thread $^{1}$ : bottles are thrown shoes;

- Looptworks: clothing from recycled materials, balls and wallets of aircraft seats;

- LanzaTech: converts carbon used as fuel and chemicals;

- Method ${ }^{2}$ : new bottles collected from the plastic of sea;

- Energizer: parched share in new batteries;

- Dell: PC helps get rid of waste;

- Levi Strauss: returns life old clothes of any brand;

- H \& M: a collection of jeans made from recycled cotton in 2015;

- Unilever: saves more than 140 thousand t. of waste transported to the landfill. The company buys more than $2 \mathrm{mln}$. t. of waste annually and recycles the same for the new packaging.

- Alaska Airlines: bags and purses from old seat aircraft.

Circular economy concept was introduced in 1990 in the context of the sustainable development strategy and proposed to solve the problems of environmental degradation and lack of resources. Circular economy operates according to the principles of 3R: Reduce, Reuse and Recycle (Potapenko, 2012, p. 11). Author proposed to consider the fourth principle - global corporate social responsibility (Responsibility), as needed in the formation of global circular value added chain.

The concept of circular economy with its principles of reduction, reuse and recycling of energy, materials and waste is seen as an alternative strategy for development in order to reduce tensions between the development of the national economy and the environment. Circular economy also helps to solve the problem of the lack of the resources and environmental pollution, and enables manufacturers to improve their competitiveness by removing green barriers in their international economic relations.

Scientific studies point out that sustainable development and entrepreneurs have the potential to create a sustainable economy and require insight into the conditions under which the business transforms the economy into a stable system. Thus, entrepreneurs create economic growth, achieving social and environmental objectives in the context of waste management. According circular economy should be considered at the micro, meso and macro levels, covering

\footnotetext{
1 Thread recently worked with Timberland, delivering processed brand from waste raw materials for the manufacture of footwear.

${ }^{2}$ Method - a large and growing «green» companies in its field. The company uses the principles of circular economy, recycling plastics collected in the sea in a new packaging.
} 
production, consumption and proper waste management (Table 1) (Potapenko, 2012, pp. 13, 19).

Table 1

Structure of circular economy

\begin{tabular}{|c|c|c|c|c|}
\hline Levels & Micro & Meso & Makro & Mega \\
\hline Production & $\begin{array}{l}\text { Environmen- } \\
\text { tally friendly } \\
\text { production }\end{array}$ & $\begin{array}{c}\text { Eco-Industrial } \\
\text { Park }\end{array}$ & Regional & \multirow{4}{*}{$\begin{array}{l}\text { Global circu- } \\
\text { lar chain of } \\
\text { added value } \\
\text { (including } \\
\text { global sup- } \\
\text { ply chains of } \\
\text { secondary } \\
\text { raw materi- } \\
\text { als) }\end{array}$} \\
\hline Consumption & Eco-design & $\begin{array}{c}\text { Eco-agriculture } \\
\text { system }\end{array}$ & $\begin{array}{c}\text { Eco- } \\
\text { Industrial } \\
\text { Network }\end{array}$ & \\
\hline $\begin{array}{l}\text { Waste Man- } \\
\text { agement }\end{array}$ & $\begin{array}{l}\text { Green pur- } \\
\text { chasing and } \\
\text { consumption }\end{array}$ & $\begin{array}{c}\text { Environmen- } \\
\text { tally friendly } \\
\text { park }\end{array}$ & $\begin{array}{l}\text { Rental, ser- } \\
\text { vice }\end{array}$ & \\
\hline $\begin{array}{c}\text { Development } \\
\text { support }\end{array}$ & \multicolumn{3}{|c|}{$\begin{array}{l}\text { Policies and laws, information platform, capac- } \\
\text { ity building; application at all levels }\end{array}$} & \\
\hline
\end{tabular}

Source: the author made on (Potapenko, 2012; Daiva, Banaite, November, 30, 2016; Akerman, Elin, 2016).

In the context of research author proposed to consider the circular economy also at a mega level, providing globalized waste management as a part of a global circular value added chain that is not identified with the global supply chain of secondary raw materials (Velis, Costas, 2015, n. d.).

A positive aspect of the circular economy policy is the absence of unexpected restrictions on development and implementation of technology. The legislation is aimed at introducing environmentally friendly technologies, but sometimes too long after the technology was developed and presented on the market. Effective enforcement of law is a prerequisite for the successful implementation of cost technological solutions using the environment. The focus of the governments in the developing and emergent countries paid into the investment for infrastructure development. Expensive environmental implementation is not a priority. International experience shows that government economic incentives are an effective means of stimulating the behavior of producers and consumers according to the principles of $3 R$.

Improvements of legislation and management systems, transparent monitoring and other actions necessary to achieve the environmental objectives of 
circular economy. Raising awareness of the business environment, raising awareness of employees and consumers equally important as the components of production, consumption and waste management. Environmental and other government agencies and scientists from various countries have made great efforts to develop and promote a common set of indicators to assess the circular economy (Electronic resource; Daiva, Banaite, November 30, 2016; Francesco di Maio, 2015; Marzena, n. d.; Akerman, Elin, 2016).

At the lowest level - the micro - depending on their characteristics and conditions different sets of indicators developed specific companies to implement circular economy in various enterprises. A set of indicators should ideally include a common set between enterprises in industry according to the specifics of a particular company. Thus, the set of indicators was developed by Chinese scientist Chang in 2009 for one company in the sector of the iron and steel production.

Herein, four indicators at the primary level, 12 at the second level indicators and 66 indicators at the highest third level were proposed. Other scientists Cheng, Du in 2009 focused on the systems performance showing them on the meso or sectoral level. These researchers used a method of analyzing the effectiveness (DEA) with nine indicators and Malmkvist ${ }^{3}$ indice for assessing production companies in the steel industry. Wu and others in 2014 analyzed the effectiveness of policies circular economy using DEA.

Other researchers (e. g. Shy et al., 2008) used 22 indexes for evaluation industrial barriers, including policies, financial, economic, technical and informational, administrative and organizational barriers. Geng in 2010 developed a system of indicators based on the power for environmental performance of one industrial park; Wang and others in 2008 examined the interaction between the barriers to energy savings.

At the meso level, two Chinese government agencies NDRC and MEP published two systems of indicators aimed at eco-industrial parks. System of NDRC has 13 indicators, grouped into four main aspects: the rate of resource production and consumption of resources, comprehensive utilization of resources and the speed reduction wastewater (Table 2), which are based on the principle of $3 \mathrm{R}$ reusing, reducing and recycling industrial waste. The system of indicators MEP has 21 indicators grouped in those same four dimensions as the system

\footnotetext{
${ }^{3}$ The index, which has found its application in the regulation of natural monopolies - index Malmquist (Malmquist productivity index, MPI) $4 \%$ - also describes changes in the performance of the company over time. This index can be decomposed into components that characterize changes in performance and technology for the period. Calculation of the index Malmquist in practice by using efficiency ratios determined by DEA.

Data Envelopment Analysis is one of the most popular methods of analysis efficiency and analysis environment is functioning. It is widely used to analyze the efficiency of industrial and agricultural enterprises, banks and medical institutions, universities and schools.
} 
NDRC, but it differs in structure and covers economic development, reduction and recycling, the fight against pollution and the administration management (Table 2).

Economists Geng and others in 2009 grouped industrial parks into three sectors integrated groups and developed three specific groups of indicators.

Table 2

The system of indicators for micro, meso, macro level implementation of circular economy

\begin{tabular}{|c|c|}
\hline Group indicators & Indicators \\
\hline \multirow{4}{*}{$\begin{array}{l}\text { Production } \\
\text { resources }\end{array}$} & Production of major mineral resources, energy output \\
\hline & The level of land use \\
\hline & The level of energy \\
\hline & The level of production (receiving) water \\
\hline \multirow{4}{*}{$\begin{array}{l}\text { Consumption } \\
\text { of resources }\end{array}$} & Energy consumption per unit of output \\
\hline & $\begin{array}{l}\text { Energy consumption per unit of output in key industries } \\
\text { (iron, copper, aluminum, cement, fertilizers, paper) }\end{array}$ \\
\hline & Water consumption per unit of output \\
\hline & Water consumption per unit of output in key industries \\
\hline \multirow{3}{*}{$\begin{array}{l}\text { Integrated use } \\
\text { of resources }\end{array}$} & The utilization of industrial solid waste \\
\hline & Re-use of industrial waste water \\
\hline & Production of major mineral resources, energy output \\
\hline \multirow{2}{*}{ Reducing waste } & The level of decrease in the rate of industrial solid waste \\
\hline & The level of deceleration of industrial waste water \\
\hline \multirow{2}{*}{$\begin{array}{l}\text { Economical } \\
\text { development }\end{array}$} & Value added per capita \\
\hline & The rate of growth of value added in industry \\
\hline \multirow{7}{*}{$\begin{array}{l}\text { Reducing } \\
\text { and recycling } \\
\text { material }\end{array}$} & $\begin{array}{l}\text { Energy consumption per unit of industrial created value } \\
\text { added }\end{array}$ \\
\hline & $\begin{array}{l}\text { Freshwater consumption per unit of industrial created } \\
\text { value added }\end{array}$ \\
\hline & $\begin{array}{l}\text { Establishment of industrial wastewater per unit of indus- } \\
\text { trial created value added }\end{array}$ \\
\hline & $\begin{array}{l}\text { The formation of solid waste per unit of industrial created } \\
\text { value added }\end{array}$ \\
\hline & Re-use of industrial waste water \\
\hline & The level of utilization of solid industrial waste \\
\hline & The level of reuse recycled treated wastewater \\
\hline \multirow[t]{2}{*}{ Fighting pollution } & The required oxygen per unit of created value added \\
\hline & 22 per unit of industrial created value added \\
\hline
\end{tabular}




\begin{tabular}{|c|l|}
\hline \hline Group indicators & \multicolumn{1}{c|}{ Indicators } \\
\hline \multirow{5}{*}{$\begin{array}{c}\text { Administration } \\
\text { and management }\end{array}$} & Level disposal of hazardous solid waste \\
\cline { 2 - 2 } & The level of speed of processing waste water \\
\cline { 2 - 2 } & The level of recycling household waste \\
\cline { 2 - 2 } & Waste collection system \\
\cline { 2 - 2 } & Environment Management System \\
\cline { 2 - 2 } & Degree setting information platforms \\
\hline & $\begin{array}{l}\text { The environmental report } \\
\text { lation quality }\end{array}$ \\
\hline & The degree of awareness of eco-industrial development \\
\hline
\end{tabular}

Source: the author compiled on the basis of (Electronic resource; Daiva, Banaite, November 30, 2016; Francesco di Maio, 2015; Marzena, n. d.; Akerman, Elin, 2016).

The system NDRC on meso level is also used at the macro level, plus another indicator: the importance of recycling materials at the regional level. This is consistent with the principles of circular economy and indicates government commitment to promoting the efficient use of resources and preservation of circular thinking. It should be noted that scientists suggest deepening system of indicators, caused by the limited focus on the principles of $3 R$ and coverage only environmental aspects. A systematic evaluation proposed in Annex 1 on the analysis of the implementation of the circular economy in China.

China is making serious efforts to implement the circular economy to ensure long-term and sustainable solutions to combat the problems of acute shortage of resources and environmental degradation. Implementation of the policy carried out on the micro, meso and macro levels, covering production, consumption and waste management. The concept of circular economy describes energy, water and various by-products and knowledge. Industrial symbiosis is an extended concept, which benefits arising from integrated economic and environmental aspects.

These common aspects of promoting competitiveness through efficient allocation of resources and increase productivity. Redesigning industrial structures reduces negative external factors and helps to improve the welfare society.

For a sustainable world, we see necessary condition - the transition from linear to circular economy. Circular economy seeks to separate economic growth from the use of natural resources and ecosystems through more effective use of these resources. By definition it is a driving force for innovation in the resource, and component reuse waste that is equivalent to new business models, particularly in the services provision. The idea is the concept of circular economy, effi- 
cient use of resources to create greater value through new product savings, development of new markets or increase existing ones.

The basic prerequisites for a new business model - circular economy (Electronic resource, 2015) are:

- Resources and pricing.

The world is under end use of cheap oil and raw materials. Lack of fossil fuels and limited natural resources of all kinds combined with increased consumer demand reflected in the problem of waste management. Simply use less is not enough and not true of today. Accordingly, the increased volatility of resources prices hinders economic growth, preventing the use risk resources;

- Increase the number of middle class.

The world has experienced two phases of middle class expansion in 1800 and is now in third. Only 525 million in Asia are middle class, which is more than the total population of the European Union ${ }^{4}$. Over the next two decades it is expected that the middle class will expand to three billion people, usually from emergent countries;

- Big data.

The emergence of the big data shifted the procedure and scope in which problems can be solved by providing deeper knowledge of the market and consumer oriented optimization solutions. This concept offers a solution to the problem of determining what and where the economy is, what has been done and the condition of, making production more effective than subtractive production ${ }^{5}$;

- Changes in legislation and globalization of management.

More and more companies are responding to various challenges, including new models of legislation and globalization of management in way of implementing new innovative projects for its products mainly in cases that previously were viewed as problems, such as the toxicity of different materials or garbage, a lot of waste which transport into a globalized circular value added chain;

- Transition from «agreement» to «relations».

Multinetwork world today reflects a new level of interaction and communication with consumers, with brands that go beyond traditional transactions. Internet interaction through Facebook, Twitter, YouTube and other web sites are a growing global phenomenon that paves the way to a new relationship customers and companies, particularly in circular chains.

\footnotetext{
${ }_{5}^{4}$ January 1, 2015 the population of the EU is estimated at 508.2 million people.

${ }^{5}$ Subtractive manufacturing is the process by which 3D-objects are built by consistently cutting material solid block by hand, but more often it is done using CNC Machine.
} 
Cooperation along the value chain often encourages successful businesses to obtain benefits from its implementation, such as reducing costs or risks, increasing income or increasing intangible assets such as brand reputation or credibility. However, this can not be achieved in isolation. Global supply chains of the recycled materials are one of the environmental solutions covering different industries (Velis, Costas, 2015). The concept of this chain can help determine potential emissions and waste management as a whole, and ensure their delivery in all stages of the product life cycle recycling.

Figure 1

The scheme formation of circular global value added chains

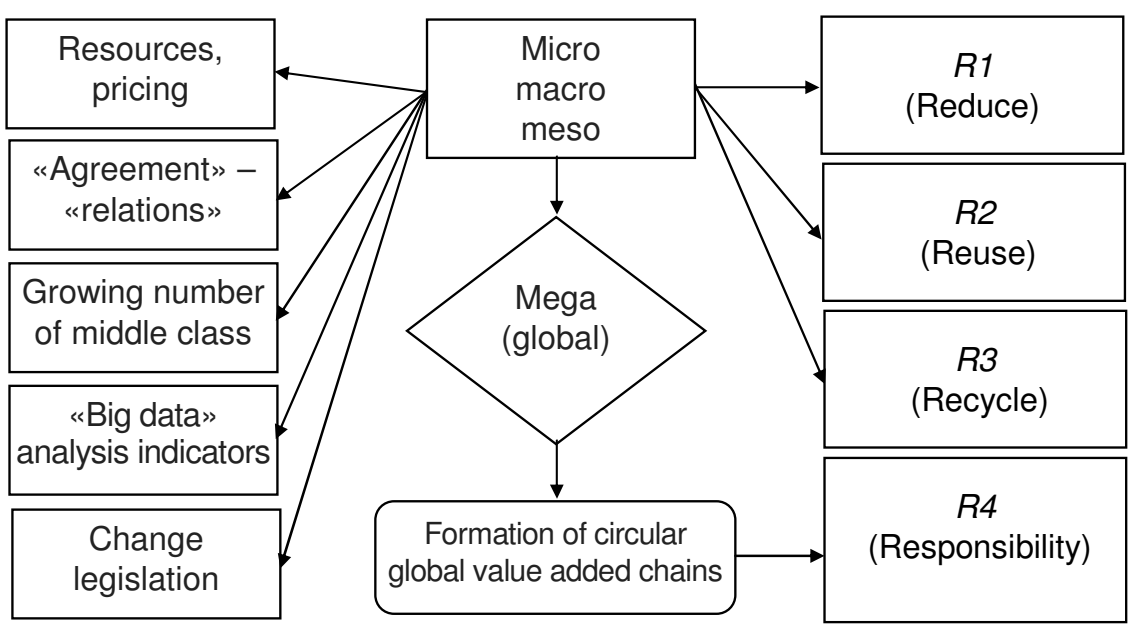

Source: made by the author.

Thus, figure 1 presents a scheme of formation of circular global value added chain according to the above mentioned approaches. It should be added that the implementation of the circular global value added chain, including the global supply chains of secondary raw materials should be based on three key drivers for successful creation of such initiatives:

1. Circular efficiency. Using all the elements of the value chain from beginning to the end with purpose to create an effective system of reduction of carbon dioxide and other waste. Initiatives that can not be achieved solely by individual 
companies can be very attractive in the supply chain within the circular (Electronic resource, 2015).

2. Finding the right partners in attracting a global initiative circular value chain requires a search outside their circle of well-known companies. The challenge is to find ideas that are best suited to address specific task value chain and build a chain with the best ability to implement these ideas. Building a successful chain requires a good understanding of the value sources- the social, economic and environmental - for all stakeholders and ensure that they are distributed on the principle of fairness and proportionality.

3. The scale of the circular initiatives. It takes time and resources from all partners and careful performance monitoring to achieve maximum effect. In order to identify opportunities to mitigate climate change must take into account all stages of production, from the early design stages ending exploitation. Often the stage at which the impact of carbon or other emissions are the largest, and is a major step circular chain with the potential to work together to reduce $\mathrm{CO}_{2}$ emissions.

In last ten years, production has shifted towards Asia due to affordability resources, the emergence of a significant segment of the middle class in the region with increasing purchasing power, which gave a decisive impetus to global trade, especially in China. Circular economy should be seen as the all process, beginning from waste and eventually transform into secondary raw materials substituting primary resources, providing equivalent functionality.

Such circular initiatives of the globalized waste management often implement in China or India. Global trade of waste for recycling is a requirement and a reality for most processing products, metals, paper and plastic.

For example, the plastic in Europe: according to the date (2014) of International Solid Waste Association (ISWA), almost half of exports of the plastic products produced with recyclable domestic waste. The majority of them (87\%) exported to China. The same situation is a typical for the US and Japan. Thus, the circular economy of plastic products in Europe and the United States largely implements through international transportation, recycling in China. There are a lot of questions relating to the environmental effectiveness of this circularity.

The fundamental issue is environmentalism and professional conditions in which the products processed. According to this Chinese government tries to reduce dependence on non-regulated, low-tech small processing operations and operates without harming the environment, which is a prerequisite for such largescale studies of Chinese scientists in the field of circular economy. 


\section{Conclusions}

More practical implementations and researches over the last ten years, describing the theoretical, methodological and empirical aspects of circular economy and its implementation. China is making serious efforts to rapidly and on a large scale to realize this idea in order to ensure long-term and sustainable solutions in the fight against acute shortage of resources and environmental degradation.

The current practice develops on the micro, meso and macro levels, covering production, consumption, waste management and various government support programs to promote, regulate, monitor and evaluate the successful implementation of circular economy.

The results show that $R \& D$ resources in China offer two systems of indicators for evaluation of circular economy. Their focus is on implementing the principles of $3 R$. In addition, one of the indicators of considering the impact of eco-industrial parks on the economy and the environment. It should also be noted that the system of indicators separated and are not standardized, and the need to coordinate efforts to harmonize them according to the heterogeneity and the specific country. This facilitates comparison of resource use and environmental performance of companies, sectors, regions and countries.

Circular economy means changes in thoughts and actions. This requires a systematic approach and affects the organization and structurization of the business model, management, law, logistics, housing, agriculture. Circular economy is a system where commodity flows effectively managed and processed, executed entirely based on renevable energy sources and any actions do not cause adverse effects on human life and ecosystems within the formation and operation of global circular value added chain. 


\section{Annex}

Table 1

Review of some empirical research on Chinese scientists' circular economy (Heshmati, Almas, 2015; Vos, Marije, n.d.; Electronic resource, n.d.).

\begin{tabular}{|c|c|c|c|c|c|}
\hline Authors & $\begin{array}{c}\text { Topic } \\
\text { of research }\end{array}$ & Time & $\begin{array}{l}\text { The system } \\
\text { of indicators }\end{array}$ & $\begin{array}{l}\text { Methods } \\
\text { of analize }\end{array}$ & Conclusions \\
\hline Peng & $\begin{array}{l}\text { Eco-friendly } \\
\text { technologies } \\
\text { in SMEs in } \\
\text { China }\end{array}$ & 2002 & $\begin{array}{l}20 \text { indicators } \\
\text { grouped into } \\
\text { four main } \\
\text { categories: } \\
\text { policy and } \\
\text { market, fi- } \\
\text { nancial, eco- } \\
\text { nomic, in- } \\
\text { formational, } \\
\text { technical, } \\
\text { managerial } \\
\text { and organ- } \\
\text { izational. }\end{array}$ & $\begin{array}{l}\text { Analytic } \\
\text { Hierarchy } \\
\text { Process }\end{array}$ & $\begin{array}{l}\text { It should take into } \\
\text { account the exter- } \\
\text { nal political and fi- } \\
\text { nancial factors than } \\
\text { internal technical } \\
\text { and management } \\
\text { indicators. The lack } \\
\text { of incentives, poor } \\
\text { compliance with } \\
\text { the rules, the high } \\
\text { capital costs were } \\
\text { the most important } \\
\text { barriers to adapta- } \\
\text { tion of clean tech- } \\
\text { nologies in China. }\end{array}$ \\
\hline $\begin{array}{l}\text { Zhang, } \\
\text { Huang }\end{array}$ & $\begin{array}{l}\text { Research } \\
\text { Scorecard } \\
\text { circular } \\
\text { economy } \\
\text { and evaluate } \\
\text { them based } \\
\text { on Nantong } \\
\text { city }\end{array}$ & $\begin{array}{l}\text { Date } \\
2002 \\
\text { aims } \\
\text { to } \\
2020\end{array}$ & $\begin{array}{l}\text { Economical } \\
\text { develop- } \\
\text { ment; reduc- } \\
\text { ing the use } \\
\text { of resources; } \\
\text { waste reduc- } \\
\text { tion; re-use } \\
\text { of resources. }\end{array}$ & $\begin{array}{l}\text { GRA (Grey } \\
\text { Relational } \\
\text { Analysis) }\end{array}$ & $\begin{array}{l}\text { In } 2002-2007 \text { the } \\
\text { aim was to reduce } \\
\text { pollution and re- } \\
\text { source consump- } \\
\text { tion; }\end{array}$ \\
\hline Wang & $\begin{array}{l}\text { Evaluation of } \\
\text { circular } \\
\text { economy in } \\
29 \text { Chinese } \\
\text { cities }\end{array}$ & 2006 & $\begin{array}{l}\text { Economical } \\
\text { develop- } \\
\text { ment; reuse } \\
\text { and recy- } \\
\text { cling; reduc- } \\
\text { ing the use } \\
\text { of resources; } \\
\text { reducing } \\
\text { emissions; } \\
\text { social devel- } \\
\text { opment. }\end{array}$ & $\begin{array}{l}\text { principal } \\
\text { component } \\
\text { analysis } \\
\text { (PCA) }\end{array}$ & $\begin{array}{l}\text { Comprehensive } \\
\text { assessment } \\
\text { showed gaps and } \\
\text { heterogeneity of } \\
\text { circular economy. }\end{array}$ \\
\hline
\end{tabular}




\begin{tabular}{|c|c|c|c|c|c|}
\hline Authors & $\begin{array}{c}\text { Topic } \\
\text { of research }\end{array}$ & Time & $\begin{array}{l}\text { The system } \\
\text { of indicators }\end{array}$ & $\begin{array}{l}\text { Methods } \\
\text { of analize }\end{array}$ & Conclusions \\
\hline $\begin{array}{l}\text { Jia, } \\
\text { Zhang }\end{array}$ & $\begin{array}{l}\text { Evaluation of } \\
\text { regional cir- } \\
\text { cular econ- } \\
\text { omy }\end{array}$ & 2006 & $\begin{array}{l}\text { The system } \\
\text { for assess- } \\
\text { ing regional } \\
\text { indices of } \\
\text { circular } \\
\text { economy in- } \\
\text { clude: re- } \\
\text { duce, recy- } \\
\text { cle and re- } \\
\text { use. }\end{array}$ & $\begin{array}{l}\text { Fuzzy logic } \\
\text { theory }\end{array}$ & $\begin{array}{l}\text { Model to assess } \\
\text { the development } \\
\text { of circular econ- } \\
\text { omy in Beijing, } \\
\text { Anhui and Si- } \\
\text { chuan. }\end{array}$ \\
\hline $\begin{array}{l}\text { Wen, } \\
\text { Meng }\end{array}$ & $\begin{array}{l}\text { Assessment } \\
\text { of industrial } \\
\text { symbiosis to } \\
\text { promote the } \\
\text { ideas of cir- } \\
\text { cular econ- } \\
\text { omy. }\end{array}$ & 2015 & $\begin{array}{l}\text { Input: water, } \\
\text { sludge con- } \\
\text { taining cop- } \\
\text { per, waste } \\
\text { copper (foil) } \\
\text { and week- } \\
\text { ends, espe- } \\
\text { cially the use } \\
\text { of copper, } \\
\text { used copper. }\end{array}$ & $\begin{array}{l}\text { Material } \\
\text { flow analy- } \\
\text { sis (MFA) }\end{array}$ & $\begin{array}{l}\text { Resource in- } \\
\text { creases with in- } \\
\text { creasing duration } \\
\text { of the industrial } \\
\text { production chain } \\
\text { and can be } \\
\text { achieved through } \\
\text { greater industrial } \\
\text { symbiosis. }\end{array}$ \\
\hline
\end{tabular}

\section{References}

1. Brutyan, M., Vahromeeva, M.P., Vorozheykyna, T. N. (2016). Problems of Modern Economy: monograms. S. Chernoff (Ed.). Novosibirsk: Publishing House.

2. Potapenko, V. (2012). Strategic priorities for safe development of Ukraine on the principles of "green economy»: monograms. Khlobystov, E. V. (Ed.)

3. Miracles of circular economy: bottles from shoes and tires. Retrieved from: http://www.bakertilly.ua/ru/news/id1065

4. Circular Economy: key solutions for climate problems. Retrieved from: http://obzor.press/press/12321-czirkulyarnaya-ekonomika-klyuch-k-resheniyuproblem-izmeneniya-klimata

5. The fourth industrial revolution: the internet of things, circular economy and block chain. Retrieved from: http://www.furfur.me/furfur/changes/changes/ 216447-4-aya-promyshlennaya-revolyutsiya 
6. Heshmati, Almas. (2015). Review of the circular economy and its implementation. Retrieved from: http://entreprenorskapsforum.se/wpontent/uploads/ 2015/12/CircularEconomy_webb.pdf

7. Vos, Marije. (n.d.). The circular economy what is it and what does it mean for you? Retrieved from: https://www.arcadis.com//en/global/cookie-wall/

8. Greening the Economy Through Life Cycle Thinking Ten Years of the UNEP/SETAC Life Cycle Initiative. Retrieved from: http://www.unep.org/

9. Measuring material flows and resource productivity. Volume I. The OECD Guide. Retrieved from: https://www.oecd.org/environment/indicatorsmodelling-outlooks/MFA-Guide.pdf.

10. Preston, Felix. (n.d.). A Global Redesign? Shaping the Circular Economy. Retrieved from: http://www.chathamhouse.org/

11. Rethinking the future. Our transition towards a circular economy. Retrieved from: http://www.philips.com/aw/about/sustainability/sustainable-planet/ circular-economy.html

12. Towards circular economy: analysis of indicators in the context of sustainable development. Retrieved from:

13. http://stics.mruni.eu/wp-content/uploads/2016/07/STICS_2016_4_142150.pdf

14. Daiva, Banaitè. (n.d.). Indicators for a circular economy EASAC policy report 30. November (2016). Retrieved from: www.easac.eu

15. The circular economy and the global economy. (2016). Retrieved from: https://www.tomra.com/en/news-and-media/news/2016/tomra-the-circulareconomy-and-the-global-economy

16. Di Maio F. (2015). A Robust Indicator for Promoting Circular Economy through Recycling. Retrieved from: http://dx.doi.org/10.4236/jep.2015.610096

17. Francesco Di Maio. (2015). Circularity indicators: An Approach to Measuring Circularity. Project overview. Retrieved from: https://www.ellenmacarthurfoundation.org/assets/downloads/insight/CircularityIndicators_Project-Overview_May2015.pdf.

18. Michela van Kampen. (2016). Measuring circularity: putting the cart before the horse? Retrieved from: http://www.innovationservices.philips.com/ news/measuring-circularity

19. Marzena Smol. (n.d.). Circular economy indicators in relation to ecoinnovation in European regions. Retrieved from: http://link.springer.com/ article/10.1007/s10098-016-1323-8

20. Akerman, Elin. (2016). Development of Circular Economy Core Indicators for Natural Resources Analysis of existing sustainability indicators as a baseline for developing circular economy indicators / Master of Science Thesis. - Stockholm. 
Vol. 16. № 1 (60). January-March 2017

ISSN 2519-4070

Retrieved from: http://www.diva-portal.org/smash/get/diva2:897309/ FULLTEXT01.pdf

21. Scaling Up Climate Action through Value Chain Mobilization. (2016). Retrieved from:

22. https://www.weforum.org/reports/scaling-up-climate-action-through-valuechain-mobilization

23. Circular business models. (2015). Retrieved from: https://groenomstilling.erhvervsstyrelsen.dk/sites/default/files/media/imsa_cir cular_business_models_-_april_2015_-_part_1.pdf

24. Velis, Costas A. (2015). Circular economy and global secondary material supply chains. Retrieved from: http://journals.sagepub.com/doi/ pdf/10.1177/ $0734242 X 15587641$

25. Incredible Examples of Circular Economy. (2016). Retrieved from: http://www.bio-bean.com/2016/06/10/7-incredible-examples-companiesembracing-principles-circular-economy/ 